\title{
Peningkatan kemampuan guru dalam pembelajaran melalui supervisi observasi kelas di SDN 02 Talun Kabupaten Pekalongan
}

\author{
Sapto Yuwono \\ SDN 02 Talun Jln. Raya Talun-Doro Kecamatan Talun Kabupaten Pekalongan
}

\begin{tabular}{|c|c|}
\hline Article Info & ABSTRACT \\
\hline Article history: & \multirow{8}{*}{$\begin{array}{l}\text { This study aims to improve the ability of teachers in learning after the } \\
\text { supervision technique of classroom observation was carried out at SD Negeri } \\
02 \text { Talun, Pekalongan Regency. This research was conducted at SD Negeri } 02 \\
\text { Talun, Pekalongan Regency for } 3 \text { months with } 2 \text { cycles. The subjects of this } \\
\text { study were class teachers from class I to class VI at SD Negeri } 02 \text { Talun. The } \\
\text { object of research is the ability of teachers in teaching and learning activities } \\
\text { and the implementation of classroom observation supervision techniques. The } \\
\text { data that will be taken during the school action research is obtained by } \\
\text { conducting observations, interviews, and documentation. By paying attention } \\
\text { to the results of research and discussion of each cycle, it can be seen that there } \\
\text { is an increase in the ability of teachers in learning planning, in managing } \\
\text { teaching and learning activities and in evaluating teaching and learning } \\
\text { activities. This proves that there is a positive influence from the } \\
\text { implementation of classroom observation supervision techniques for } \\
\text { improving teacher abilities and encouraging improvements in optimal } \\
\text { learning. It is hoped that the results of this study will motivate the principal to } \\
\text { carry out classroom observation supervision techniques as well as possible and } \\
\text { position himself as a good role model and learning leader. }\end{array}$} \\
\hline Received : 30 Agustus 2021 & \\
\hline Revised : 27 September 2021 & \\
\hline Accepted: 29 September 2021 & \\
\hline Keywords: & \\
\hline & \\
\hline techniques; teacher's at & \\
\hline & \\
\hline
\end{tabular}

(*) Corresponding Author:

saptotalun@gmail,com

How to Cite: Yuwono, S. (2021). Peningkatan kemampuan guru dalam pembelajaran melalui supervisi observasi kelas di SDN 02 Talun Kabupaten Pekalongan. Action Research Journal, 1(1): 94-106.

\section{PENDAHULUAN}

Guru merupakan salah satu sumberdaya manusia di sekolah, yang memiliki peran penting. Proses penyelenggaraan pendidikan di sekolah tidak akan dapat berjalan jika tidak ada guru. Pemberdayaan guru menjadi tugas penting yang harus dapat diwujudkan oleh kepala sekolah di sekolah, sehingga guru dapat bekerja produktif seperti mengajar dengan penuh tanggungjawab, berusaha menjalankan tugasnya dengan sebaik mungkin dan sebagainya.

Di SD Negeri 02 Talun Kabupaten Pekalongan, menurut hasil pengamatan penulis selama melaksanakan teknik supervisi observasi kelas, dapat diketahui bahwa lebih dari 50 persen guru SD Negeri 02 Talun ketika melaksanakan tugas pokoknya belum memahami benar landasan pendidikan dan kurikulum berbasis kompetensi tahun 2006 yang selanjutnya dijabarkan dalam bentuk KTSP pada satuan pendidikan masing-masing. Kebanyakan guru belum mengembangkan sendiri silabus, RPP hingga alat evaluasinya dalam penilaian kelas. Demikian pula dengan proses pembelajarannya, guru belum mempraktekkan model-model atau metode-metode pembelajaran yang menjadi tuntutan saat ini seperti pembelajaran kontekstual, pembelajaran realistik, dan pembelajaran konstruktivisme lainnya.

Sementara fakta menunjukkan bahwa pelaksanaan program Teknik supervisi observasi kelas pada sekolah-sekolah formal kurang berhasil. Kepala Sekolah belum optimal melaksanakan perencanaan teknik supervisi observasi kelas, sesuai perencanaan, monitoring dan evaluasi pelaksanaan Teknik supervisi observasi kelas dan tindak lanjut hasil pelaksanaan supervisi yang sering dilakukan adalah Kepala Sekolah menyampaikan informasi-informasi yang sifatnya umum 
atau penting baik yang berasal dari dinas, Pemerintah Daerah, LPMP atau dari Menteri Pendidikan dan Kebudayaan, bahkan sering terjadi kerja Kepala Sekolah dilakukan sebagai kegiatan seremonial saja. Kepala Sekolah datang ke sekolah hanya untuk konfirmasi, sehingga jarang bertemu atau mengadakan pembinaan terhadap guru. Kepala Sekolah lebih banyak memonitor perangkat pembelajaran saja dan jarang memantau praktek pembelajarannya.. Teknik supervisi observasi kelas yang seharusnya mampu meningkatkan kemampuan profesional guru sebagai upaya mewujudkan pembelajaran yang berkualitas dan pemberdayaan guru tidak tercapai secara optimal.

Berbagai usaha untuk meningkatkan kualitas guru dan pendidikan guru telah dilaksanakan dengan berbagai bentuk. Misalnya, pemerintah melalui Menteri Pendidikan dan Kebudayaan telah membuatkan pedoman pengembangan silabus. Kepala Sekolah telah melaksanakan supervisi pengajaran secara rutin. Dan memberikan kesempatan kepada semua guru untuk menjadi guru pembelajar sebagaimana diprogramkan oleh pemerintah saat ini. Pengakuan bahwa guru adalah tenaga professional telah ditegaskan dalam undang-undang No 20 tahun 2003 tentang Sistem Pendidikan Nasional pasal 29. "Pendidik merupakan tenaga professional yang bertugas merencanakan dan melaksanakan tugas pembelajaran , menilai hasil pembelajaran dan...."

Walaupun jabatan guru telah diakui sebagai profesi belum berarti semua guru sudah profesional. Semua guru telah menyadari bahwa seorang guru harus professional namun masih sedikit yang sadar untuk berusaha mengembangkan diri untuk menjadi guru yang professional. Sangat sedikit guru yang mampu melihat kelemahan dirinya dalam melaksanakan profesinya. Suatu contoh masih sering dijumpai guru melimpahkan kesalahan kepada siswa bila siswa tidak berhasil mencapai prestasi belajar yang diharapkan tanpa ada usaha untuk melihat kekurangan yang ada pada diri guru itu sendiri. Hasil Capaian SPM Dikdas pada tahun 2015 diperoleh data bahwa jumlah guru tetap yang rata-rata jam kerja per minggu $\geq 37,5$ di Dinas Pendidikan dan Kebudayaan Kabupaten Peklongan baru mencapai 38,30\%. Jumlah SD atau MI yang kepala sekolahnya melakukan supervisi kelas dan memberikan umpan balik kepada guru dua kali dalam setiap semester hanya 5,43\%. (Sumber : Dindikbud Kab. Pekalongan pada Pelatihan SPM Desember 2015). Sungguh ironis jika kita tinjau dari status sebagai guru profesional dengan tunjangan profesinya yang tidak seimbang dengan kinerjanya

Atas dasar kenyataan tersebut, dalam mengembangkan profesi guru memerlukan batuan agar guru dapat menyadari bahwa ada kelemahan pada dirinya dalam mengelola proses pembelajaran dan menemukan upaya pemecahannya. Penelitian yang berfokus pada profesionalisme dan kompetensi pedagogik dan profesionalisme guru ini dilakukan untuk memperoleh perspektif berbeda dari penelitian-penelitian terdahulu tentang fungsi teknik supervisi observasi kelas oleh Kepala Sekolah sebagai supervisor dalam hubungannya dengan kemampuan guru. Untuk memantau pelaksanaan tugas guru ini apakah sudah sejalan dengan kurikulum yang berlaku dan bagaimana kinerja seorang guru dalam menjalankan tugasnya, terdapat sistem kontrol melalui supervisi berkesinambungan yang dilaksanakan oleh Kepala Sekolah. Peranan Kepala Sekolah selain memantau pelaksanaan perkembangan proses pembelajaran juga diharapkan membantu para guru untuk lebih mempotensikan dirinya. Kepala Sekolah sebagai supervisor, motivator, sekaligus inovator dalam memajukan pendidikan, berkewenangan untuk mengarahkan, membimbing, membina para guru di sekolahnya, dan arus menjaga kemampuan guru-gurunya tetap up to date, memonitor keseragaman dan kualitas produkditivitas.

Berdasarkan latar belakang yang telah dikemukakan di atas, maka masalah dalam penelitian ini dapat dirumuskan: Apakah kemampuan guru dalam mengajar dapat meningkat setelah dilaksanakan Supervisi Teknik Observasi Kelas di SD Negeri 02 Talun Kabupaten Pekalongan?

Sejalan dengan rumusan masalah yang dikemukakan, maka tujuan penelitian tindakan sekolah ini adalah untuk mengetahui kehandalan tindakan yaitu meningkat tidaknya kemampuan 
guru dalam pembelajaran setelah dilaksanakan Teknik supervisi observasi kelas di SD Negeri 02 Talun Kabupaten Pekalongan.

\section{KAJIAN PUSTAKA}

Istilah supervisi berasal dari dua kata, yaitu "super" dan "vision". Dalam Webstr's New World Dictionari istilah super berarti "higher in rank or position than, superior to (superintendent), a greater or better than others" (1991:1343) sedangkan kata vision berarti "the ability to perceive something not actually visible, as through mental acutness or keen foresight (1991:1492). Seorang supervisor adalah seorang yang profesional ketika menjalankan tugasnya, ia bertindak atas dasar kaidah-kaidah ilmiah untuk meningkatkan mutu pendidikan. Secara etimologis, supervisi menurut S. Wajowasito dan W.J.S Poerwadarminta yang dikutip oleh Ametembun (1993:1) : "Supervisi dialihbahasakan dari perkataan inggris "Supervision" artinya pengawasan. Pengertian supervisi secara etimologis masih menurut Ametembun (1993:2), menyebutkan bahwa dilihat dari bentuk perkataannya, supervisi terdiri dari dua buah kata super + vision : Super $=$ atas, lebih, Vision $=$ lihat, tilik, awasi. Makna yang terkandung dari pengertian tersebut, bahwa seorang supervisor mempunyai kedudukan atau posisi lebih dari orang yang disupervisi, tugasnya adalah melihat, menilik atau mengawasi orang-orang yang disupervisi.

Pengertian supervisi secara semantik adalah pengertian yang dirumuskan oleh para ahli, untuk memperoleh suatu gambaran komparatif. Berikut ini beberapa definisi mengenai supervisi di bidang pendidikan. Supervisi adalah pengawasan profesional dalam bidang akademik dijalankan berdasarkan kaidah-kaidah keilmuan tentang bidang kerjanya, memahami tentang pembelajaran lebih mendalam dari sekadar pengawas biasa. Para ahli dalam bidang administrasi pendidikan memberikan kesepakatan bahwa teknik supervisi observasi kelas merupakan disiplin ilmu yang memfokuskan diri pada pengkajian peningkatan situasi belajarmengajar, seperti yang diungkapkan oleh ( Gregorio, 1966, Glickman Carl D, 1990, Sergiovanni, 1993 dan Gregg Miller, 2003). Hal ini diungkapkan pula dalam Association for Supervision and Curriculum Development, 1987:129) yang menyebutkan sebagai berikut: Almost all writers agree that the primery focus in educational supervision is-and should be-the improvement of teaching and learning. The term instructional supervision is widely used in the literatur of embody all effort to those ends. Some writers use the term instructional supervison synonymously with general supervision.

Menurut Pidarta (2009: 2) teknik supervisi observasi kelas adalah kegiatan membina para pendidik dalam mengembangkan proses pembelajaran, termasuk segala unsur penunjangnya. Sementara itu yang dimaksud dengan supervisi kontekstual adalah upaya membina guru-guru dalam mengembangkan proses pembelajaran pada daerah tertentu yang mencakup unsur-unsur: 1) materi pelajaran, 2) proses pembelajaran, 3) kecakapan hidup yang dibutuhkan, 4) tingkat kompetensi setiap guru, dan 5) kondisi para siswa..

Kemampuan berasal dari kata dasar mampu, memiliki arti kesanggupan, kecakapan atau kekuatan (Depdikbud, 2001: 707). Istilah kemampuan biasanya dikaitkan dengan potensi seseorang untuk menguasai suatu keahlian. Kemampuan menjadi modal dasar yang harus dimiliki oleh seorang guru dalam menjalankan tugasnya. Terutama kemampuan melaksanakan pembelajaran dan panilaian hasil belajar. Seorang guru akan dapat menjalankan tugasnya dengan baik apabila didukung oleh kemampuan yang baik. Kemampuan melaksanakan tugas bagi seorang guru diperoleh melalui proses pendidikan. Kemampuan tersebut sangat diperlukan guna menjalankan fungsi profesinya. Dalam pengertian profesionalisme telah tersirat adanya sutau keharusan memiliki kemampuan agar profesi tersebut dapat berfungsi sebaik-baiknya.

Menurut Zainal Aqib (2002: 84-86), dalam menjalankan tugasnya, seorang guru hendaknya memiliki kemampuan dan sikap, yaitu (1) menguasai kurikulum, (2) menguasai materi,(3) menguasai metode dan evaluasi belajar,(4) setia terhadap tugas, dan (5) disiplin dalam arti luas. Depdikbud sejak tahun 1980 telah merumuskan sepuluh kemampuan dasar guru, yaitu: (1) menguasai bahan ajar, (2) mampu mengelola program belajar mengajar, (3) mampu mengelola kelas, (4) mampu menggunakan media dan sumber belajar, (5) menguasai landasan pendidikan, 
(6) mampu mengelola interaksi belajar mengajar, (7) mampu menilai prestasi belajar siswa untuk kepentingan pengajaran, (8) mengenal fungsi serta program bimbingan dan penyuluhan, (9) mengenal dan mampu ikut penyelenggaraan administrasi sekolah, dan (10) memahami prinsip prinsip penelitian pendidkan untuk kepentingan pengajaran (Saman, 1994:61-68).

Pengertian lain menyatakan bahwa kemampuan menguasai sesuatu disebut kompetensi. Kemampuan Guru disebut juga kompetensi guru.

Menurut Undang - Undang Tahun 2005 Nomor 14 pasal 1 tentang Guru dan Dosen, kompetensi adalah seperangkat pengetahuan, keterampilan, dan perilaku yang harus dimiliki, dihayati, dan dikuasai dalam melaksanakan tugas keprofesionalan. Kompetensi tersebut akan terwujud dalam bentuk penguasaan pengetahuan dan perbuatan secara professional dalam menjalankan fungsi sebagai guru,

Kompetensi guru menurut pasal 10 Undang-Undang Tahun 2005 Nomor 14 tentang Guru dan Dosen meliputi: kompetensi pedagogik, kompetensi kepribadian, kompetensi sosial, dan kompetensi profesional. Kompetensi guru tersebut di dalam Peraturan Menteri Pendidikan Nasional Tahun 2007 Nomor 16 tentang standar kualifikasi akademik dan kompetensi guru mata pelajaran diuraikan sebagai berikut. Pertama, kompetensi pedagogik meliputi: (1) menguasai karakteristik peserta didik dari aspek fisik, moral, spiritual, sosial, cultural, emosional, dan intelektual; (2) menguasai teori belajar dan prinsip-prinsip pembelajaran yang mendidik; (3) mengembangkan kurikulum yang terkait dengan mata pelajaran yang diampu; (4) menyelenggarakan pembelajaran yang mendidik; (5) memanfaatkan teknologi informasi dan komunikasi untuk kepentingan pembelajaran; (6) memfasilitasi pengembangan potensi peserta didik untuk mengaktualisasikan berbagai potensi yang dimiliki; (7) berkomunikasi secara efektif, empatik, dan santun dengan peserta didik; (8) menyelenggarakan penilaian dan evaluasi proses dan hasil belajar; (9) memanfaatkan hasil penilaian dan evaluasi untuk kepentingan pembelajaran; dan (10) melakukan tindakan reflektif untuk peningkatan kualitas pembelajaran.

Undang-undang Nomor 14 Tahun 2005, Pasal 8 yang menyatakan bahwa guru wajib memiliki kualifikasi akademik, kompetensi, sertifikat pendidik, sehat jasmani dan rohani, serta memiliki kemampuan untuk mewujudkan tujuan pendidikan nasional. Sertifikat pendidik bagi guru dalam jabatan diperoleh melalui sertifikasi dengan penilaian portofolio atau melalui jalur pendidikan. Sementara menurut Sidjabat (2003:46-49), sebagai seorang guru, sangat dituntut untuk memiliki dan mengembangkan kemampuan serta kemampuannya di bidang mengajar.

\section{METODE PENELITIAN}

Penelitian tindakan sekolah ini dilaksanakan di SD Negeri 02 Talun Kabupaten Pekalongan selama 3 bulan mulai bulan Februari sampai dengan bulan April 2016. Penelitian dilaksanakan sebanyak 2 siklus. Berada di daerah pinggiran kota (pedesaan) dengan input siswa memiliki kesadaran untuk belajar yang cukup baik. Subyek penelitian ini adalah guru kelas dari kelas I sampai dengan kelas VI di SD Negeri 02 Talun. Adapun sebagai obyek dalam penelitian ini adalah kemampuan guru dalam kegiatan belajar mengajar dan pelaksanaan teknik supervisi observasi kelas

Data yang diambil dalam penelitian tindakan sekolah bersumber antara dari dokumen kegiatan pembelajaran yang pernah dilakukan baik foto kegiatan maupun hasil Supervisi oleh Kepala Sekolah, kegiatan-kegiatan yang muncul selama proses Supervisi atau aktivitas guru dalam kegiatan pembelajaran dan dari keterangan siswa. Data yang akan diambil selama penelitian tindakan sekolah diperoleh dengan cara melakukan observasi, wawancara, dan dokumentasi. Observasi dilaksanakan dengan menggunakan instrumen pengukuran kemampuan guru dalam kegiatan pembelajaran, lembar observasi dan lembar penilaian peer-assessment untuk mengukur indikator-indikator kerja dan efisiensi selama kegiatan pembelajaran. Wawancara dilaksanakan dengan menggunakan kuisener untuk mengungkap kemampuan guru dalam pembelajaran. Dokumentasi dilaksanakan dengan mencatat dan mengabadikan kegiatan guru dalam kegiatan pembelajaran sebagai bahan evaluasi bagi supervisor. 
Dalam penelitian tindakan sekolah ini, validasi data dicapai dengan menggunakan data triangulation dan instrumental triangulation. Data triangulation atau triangulasi data dilakukan dengan mengambil data dari berbagai suasana, waktu, tempat dan jenis. Sedang instrumental triangulation dilakukan dengan menggunakan berbagai jenis alat/instrumen. Data yang diperoleh dalam penelitian tindakan sekolah ini, akan dianalisa dengan menggunakan analisis deskriptif, yang disertai dengan analisis kualitatif untuk mendukung data di atas

Indikator kinerja sejalan dengan tujuan dari penelitian tindakan sekolah ini adalah (1) meningkatnya teknik supervisi obesrvasi kelas yang kondusif yang merupakan penerapan dari konsep dan keterampilan dasar supervisi, tujuan serta prinsip supervisi, dan (2) meningkatnya kemampuan guru dalam pembelajaran bahasa indonesia yang merupakan penerapan kemampuan merancang pembelajaran, melaksanakan pembelajaran dan evaluasi. Penelitian ini merupakan penelitian tindakan sekolah. dengan pusat penekanan pada upaya peningkatan kemampuan guru dalam pembelajaran. Penelitian ini lebih memfokuskan pada penerapan Teknik supervisi observasi kelas sebagai upaya untuk meningkatkan kemampuan guru dalam pembelajaran dalam kegiatan yang berbentuk Randoms Siclus, sebanyak 2 (tiga) siklus, dengan mengacu pada model yang diadaptasi dari Hopkins (1993:48). Setiap siklus prosedur atau langkah-langkah yang akan dilakukan dalam penelitian ini dilaksanakan terdiri dari empat komponen kegiatan pokok, yaitu: (a) perencanaan (planning); (b) tindakan (acting); (c) pengamatan (observing); (d) refleksi (reflecting), yang pada pelaksanaannya keempat komponen kegiatan pokok itu berlangsung secara terus menerus dengan diselipkan modifikasi pada komponen perencanaan berupa perbaikan perencanaan.

Spiral Penelitian Tindakan Kelas:

1.Rencana

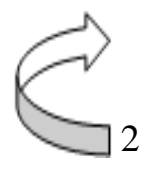

3.Refleksi

2. Tindakan/Pengamatan

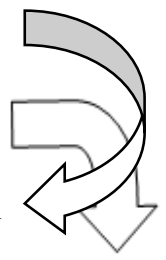

4. Perbaikan

1. Rencana

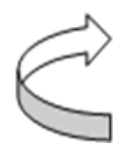

3. Refleksi
2. Tindakan/Pengamatan

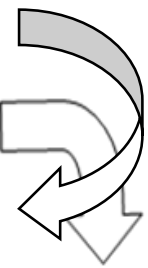

4. Perbaikan

1. Rencana

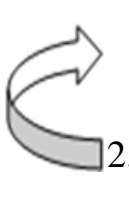

\section{Refleksi}

2. Tindakan/Pengamatan

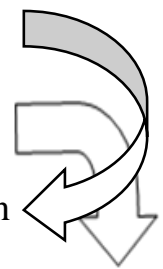

Sumber: Adaptasi dari Hopkins 1993:48

Adapun proses penelitian dijelaskan sebagai berikut :

a. Perencanaan tindakan (Planning)

1). Menetapkan jumlah siklus yaitu 2 siklus. Tiap siklus 1-2 kali tatap muka pembelajaran. 2). Memberi tugas kepada kolaborator dan peneliti sendiri untuk melakukan pengamatan/supervisi pada guru Bahasa Indonesia. Mengingat jumlah subyek penelitian yang cukup banyak.3). Menyusun rencana supervisi (supervition plan) .4). Mempersiapkan instrumen 
penilaian. Khususnya pada penyusunan rencana supervisi maupun instrumen supervisi/penilaian, peneliti mengacu pada kompetensi pedagogik yang harus dimiliki guru sebagai syarat guru yang profesional yang merupakan kemampuan guru dalam mengelola pembelajaran, sekurangkurangnya meliputi (1) pemahaman wawasan atau landasan kependidikan, (2) pemahaman terhadap peserta didik, (3) pengembangan kurikulum/silabus, (4) perancangan pembelajaran, (5) pelaksanaan pembelajaran yang mendidik dan dialogis, (6) pemanfaatan teknologi pembelajaran, (7) evaluasi proses dan hasil belajar, dan (8) pengembangan peserta didik untuk mengaktualisasikan berbagai potensi yang dimilikinya.

b. Implementasi Tindakan (action)

Pada tahap ini peneliti melaksanakan tindakan (action) untuk meningkatkan kemampuan guru dalam pembelajaran melalui beberapa siklus. Dengan memperhatikan unsur kompetensi pedagogik yang ada maka teknik supervisi observasi kelas dilaksanakan dalam tiga tahapan, yakni:

\section{1). Tahap I}

Tindakan dalam tahap 1 meliputi: a). Melaksanakan wawancara yang berkaitan dengan pemahaman guru tentang wawasan dan landasan pendidikan serta karakteristik peserta didik.b). Penilaian persiapan mengajar ditinjau dari perangkat pembelajaran, buku penunjang, dan alat bantu percepatan pembelajarannya. Dalam bagian ini, bagaimana pengembangan kurikulum/silabus dan perancangan pembelajaran akan terpantau. Dan kesiapan guru dalam mengajar juga dapat diukur.

\section{2). Tahap II}

Tindakan dalam tahap kedua ini, supervisor melaksanakan teknik supervisi observasi kelas terhadap jalannya proses belajar mengajar. Kemampuan guru dalam (i) melaksanakan pembelajaran yang mendidik dan dialogis, (ii) memanfaatkan teknologi pembelajaran, (iii) mengevaluasi proses dan hasil belajar, dan (iv) pengembangan peserta didik untuk mengaktualisasikan berbagai potensi yang dimilikinya akan dinilai dalam tahapan ini.

3). Tahap III

Tindakan dalam tahap ketiga ini, supervisor bersama kolabolator melaksanakan tindak lanjut terhadap hasil supervisi dalam rangka peningkatan kemampuan guru dalam mengajar.

c. Pemantauan (Observing)

Untuk mengetahui sejauhmana efektifitas tindakan sekolah ini dilakukan, maka diperlukan instrumen-instrumen pengamatan dan evaluasi yang terinci sehingga dapat digunakan alat ukur keberhasilan (measure echievement). Data diperoleh melalui observasi, wawancara, dan dokumentasi. Cara pengamatan dilaksanakan oleh kolaborator dan peneliti.

d. Refleksi (reflection)

Untuk mengetahui kelemahan dan kelebihan tindakan sekolah setiap siklus sebagai bahan acuan perbaikan pada tindakan sekolah berikutnya, maka diperlukan analisis masalah yang terjadi terutama yang berkaitan dengan penerapan instrumen supervisi, perkembangan kemampuan guru dalam pembelajaran, tanggapan, dan rencana supervisi berikutnya. Pada tahap ini rumusan masalah yang digunakan sebagai pedoman keberhasilan, antara lain: Apakah proses pelaksanaan supervisi telah sesuai dengan rencana?, Bagaimana tingkat kemajuan kemampuan guru dalam pembelajaran? Perubahan apa yang terjadi pada guru?m.

\section{HASIL PENELITIAN DAN PEMBAHASAN Deskripsi Kondisi Awal}

Subyek penelitian tindakan sekolah ini adalah guru kelas SD Negeri 02 Talun Kabupaten Pekalongan. Jumlah subyek secara keseluruhan adalah 6 orang. Terdiri dari guru kelas I sampai dengan kelas VI. Latar belakang mereka antara lain : (i) berasal dari lulusan LPTK yang berbedabeda, (ii) sebagian besar belum melaksanakan model-model pembelajaran inovatif, dan (iii) semangat mengajarnya masih perlu ditingkatkan. Dari instrumen-instrumen yang telah disiapkan untuk menjaring data awal (pra-tindakan penelitian) melalui dokumentasi dan observasi. 


\section{Hasil Penelitian}

Dalam penelitian ini, kemampuan guru dalam pembelajaran bahasa Indonesia meliputi: (1) kemampuan guru dalam perencanaan KBM, (2) kemampuan guru alam pengelolaan KBM, dan (3) kemampuan dalam penilaian KBM.

1. Hasil pengukuran kemampuan dalam perencanaan KBM

Data tentang kemampuan guru dalam merencanakan kegiatan belajar mengajar yang diperoleh dari pelaksanaan teknik supervisi observasi kelas pada siklus I dan siklus II meliputi : (1) motivasi guru dalam perencanaan KBM dan (2) kegiatan guru dalam perencanaan KBM yang dapat dilihat pada grafik dibawah ini:

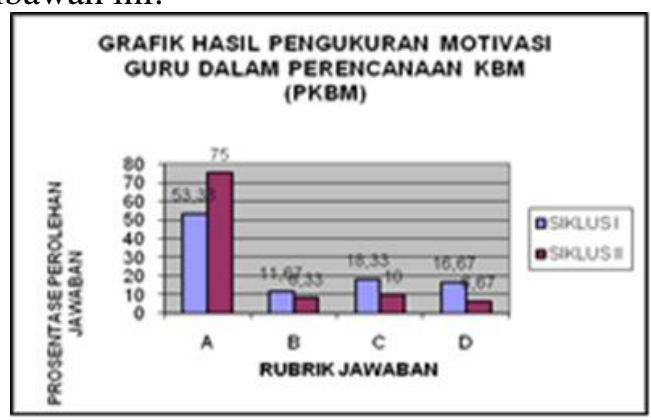

Gambar 1 Hasil Pengukuran Motivasi Guru dalam Perencanaan KBM

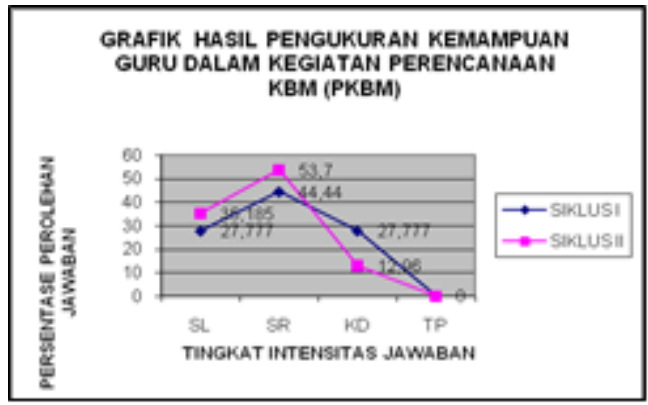

Gambar 2. Hasil Pengukuran Kemampuan Guru dalam Kegiatan Perencanaan KBM

2. Hasil pengukuran kemampuan dalam pengelolaan KBM

Data tentang kemampuan guru dalam mengelola kegiatan belajar mengajar yang diperoleh dari hasil pelaksanaan teknik supervisi observasi kelas pada siklus I dan siklus II meliputi : (1) kemampuan mengelola ketertiban, (2) kemampuan mengelola pembelajaran, (3) kemampuan mengelola alat dan media pembelajaran, (4) kemampuan mengelola ruang, (5) kemampuan mengelola waktu, (6) kemampuan mengelola individu dan kelompok, dan (7) kemampuan memimpin kelas. Hasil pengukuran ketujuh kemampuan dalam pengelolaan KBM tersebut beserta rekapannya dapat dilihat pada grafik dibawah ini:

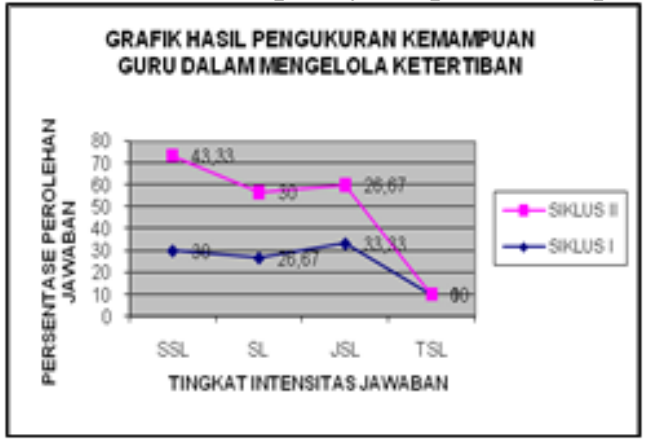

Gambar 3. Hasil Pengukuran Kemampuan Guru Mengelola Ketertiban dalam KBM

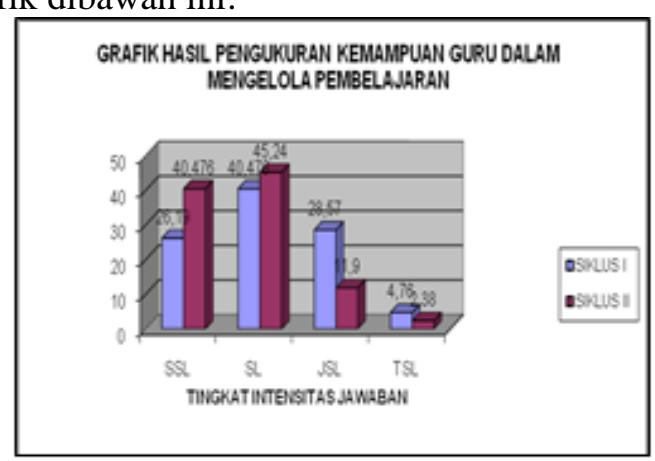

Gambar 4. Hasil Pengukuran Kemampuan Guru dalam Mengelola Pembelajaran 


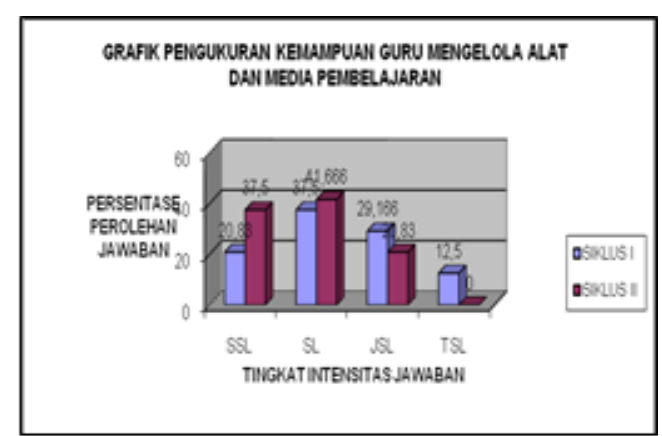

Gambar 5. Hasil Pengukuran Kemampuan Guru dalam Mengelola Alat dan Media Pembelajaran

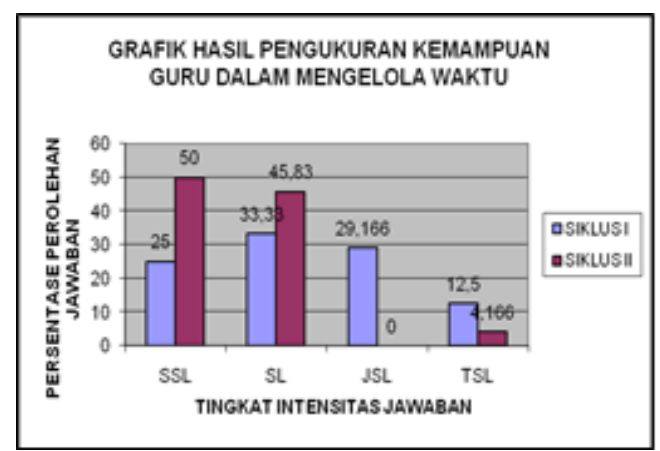

Gambar 7. Hasil Pengukuran Kemampuan Guru dalam Mengelola Waktu

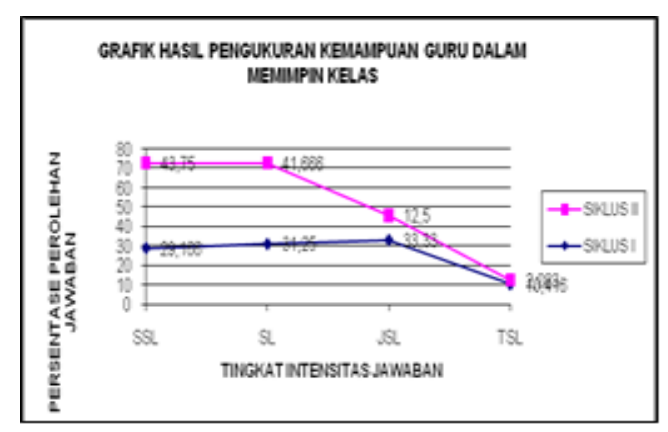

Gambar 9. Hasil Pengukuran Kemampuan Guru dalam Memimpin Kelas

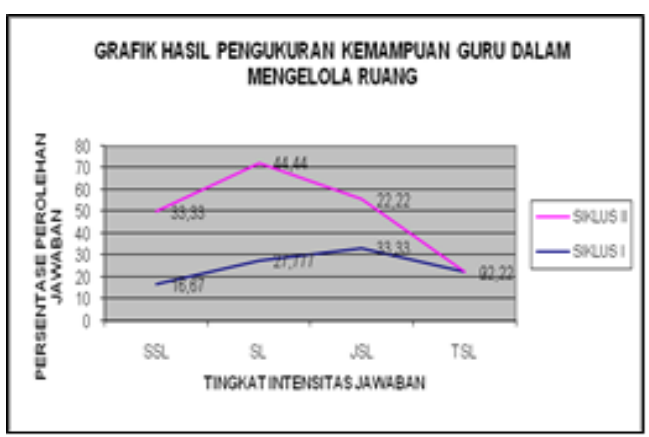

Gambar 6. Hasil Pengukuran Kemampuan Guru dalam Mengelola Ruang

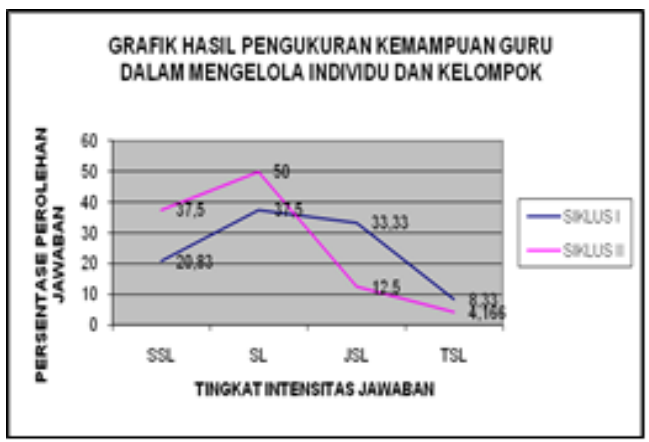

Gambar 8. Hasil Pengukuran Kemampuan Guru dalam Mengelola Individu dan Kelompok

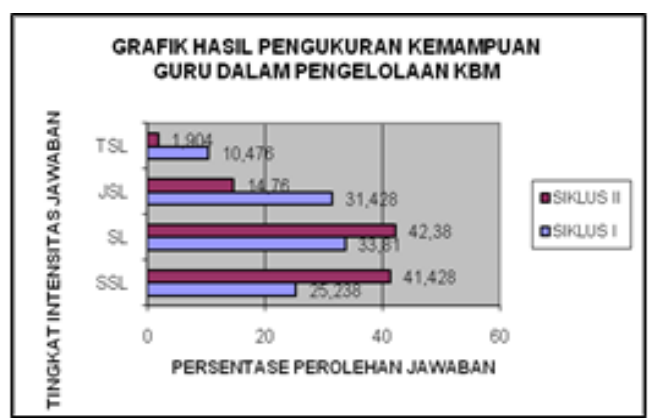

Gambar 10. Rekap Hasil Pengukuran Kemampuan Guru dalam Pengelolaan KBM

\section{Hasil pengukuran kemampuan dalam Evaluasi KBM}

Data tentang kemampuan guru dalam evaluasi kegiatan belajar mengajar yang diperoleh dari hasil pelaksanaan teknik supervisi observasi kelas pada siklus I dan siklus II meliputi : (1) hasil pengukuran kemampuan guru dalam waktu penilaian , (2) hasil pengukuran kemampuan guru dalam penentuan jenis ulangan, (3) hasil pengukuran kemampuan guru dalam penentuan bentuk jawaban, (4) hasil pengukuran kemampuan guru dalam penentuan bentuk soal, (5) hasil pengukuran kemampuan guru dalam mengambil sumber soal, (6) hasil pengukuran sebab kesalahan dalam penilaian, dan (7) hasil pengukuran kemampuan guru dalam tindak lanjut penilaian dapat dilihat pada grafik di bawah ini: 


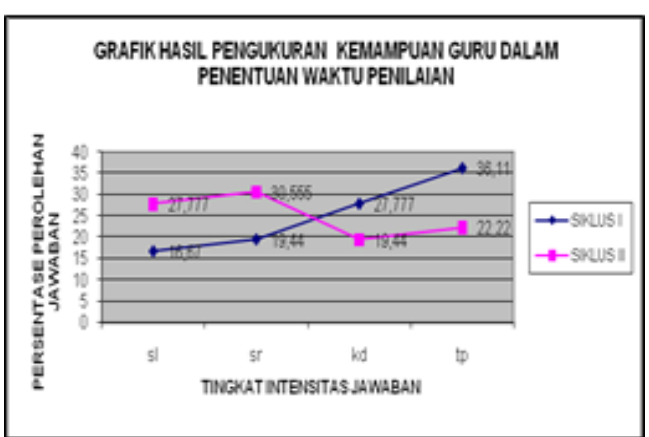

Gambar 11. Hasil Pengukuran Kemampuan Guru Dalam Waktu Penilaian

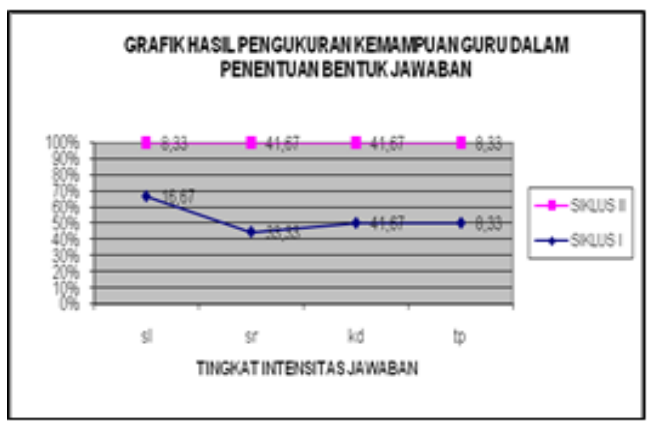

Gambar 13. Hasil Pengukuran Kemampuan Guru Dalam Penentuan Bentuk Jawaban

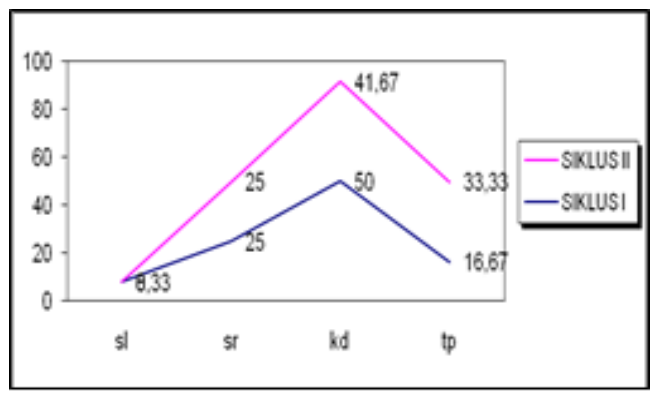

Gambar 15. Hasil Pengukuran Kemampuan Guru Dalam Mengambil Sumber Soal

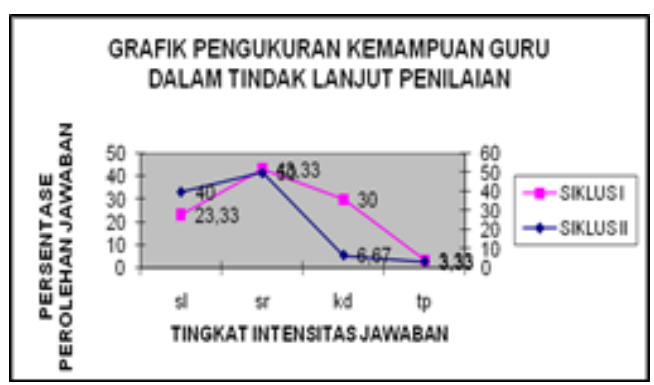

Gambar 17. Hasil Pengukuran Kemampuan Guru Dalam Tindak Lanjut Penilaian

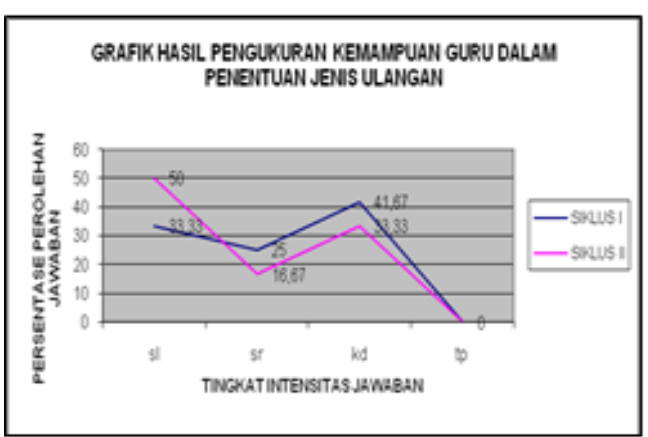

Gambar 12. Hasil Pengukuran Kemampuan Guru Dalam Penentuan Jenis Ulangan

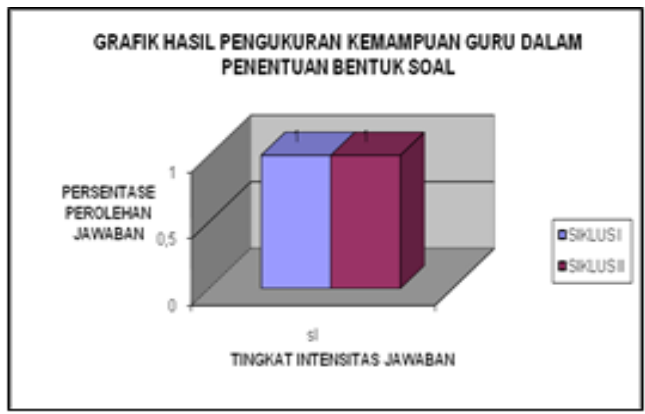

Gambar 14. Hasil Pengukuran Kemampuan Guru Dalam Penentuan Bentuk Soal

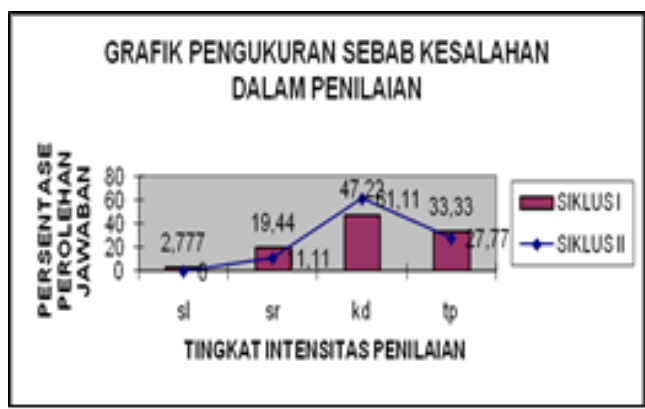

Gambar 16. Hasil Pengukuran Sebab Kesalahan Dalam Penilaian

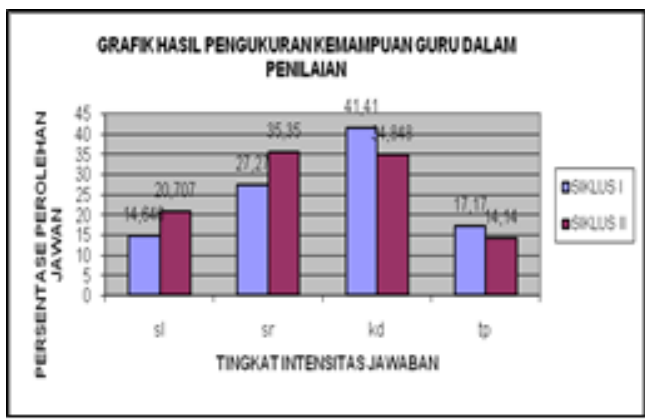

Gambar 18. Rekap Hasil Pengukuran Kemampuan Guru dalam Penilaian 
4. Hasil pengukuran kinerja supervisor dalam pelaksanaan teknik supervisi observasi kelas.

Data tentang kinerja supervisor dalam pelaksanaan teknik supervisi observasi kelas dapat dilihat pada grafik di bawah ini :

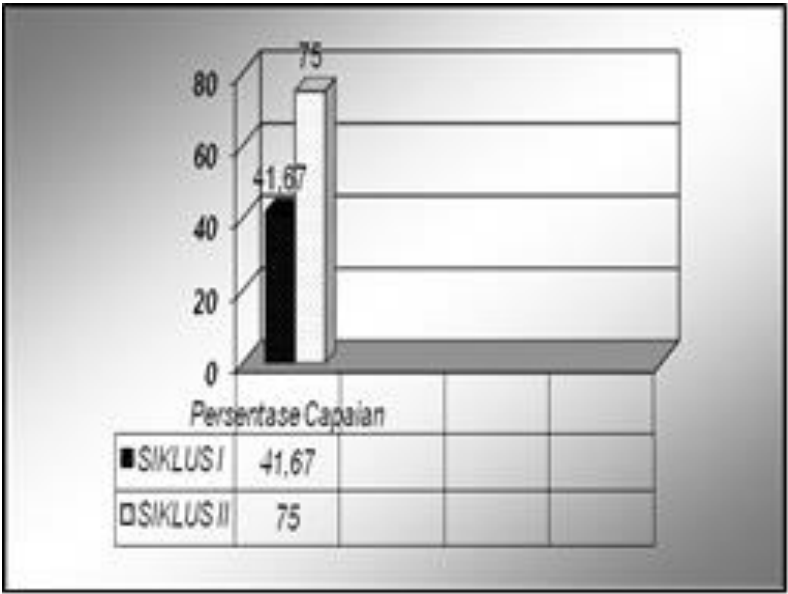

Gambar 19. Hasil Pengukuran Kinerja Supervisor dan Pelaksanaan Teknik Supervisi Observasi Kelas

\section{Pembahasan}

Pembahasan tiap siklusnya a. Siklus I

Dengan memperhatikan data yang ada dalam grafik di atas, tampak bahwa jawaban A yang paling banyak dipilih dari 6 guru subyek penelitian yaitu sebesar 53,33\%. Pada dataran motivasi , perencanaan dilaksanakan karena merasa bahwa itu kewajibannya sebagai guru. Sementara persentase perolehan jawaban B,C dan D lebih kecil yang menunjukkan bahwa guruguru kelas di SD Negeri 02 Talun memang mempunyai kesadaran yang cukup tinggi atas kewajiban guru. Namun yang menjadi persoalan adalah kebiasaan membaca kurikulum, pedoman pengembangan silabus, dan tujuan kurikulum mata pelajaran masih rendah. Penulis berasumsi, apabila para guru menjadikan kegiatan membaca kurikulum, pedoman pengembangan silabus dan tujuan kurikulum mata pelajaran menjadi kebiasaan , maka motivasi guru akan lebih optimal. Karena dengan membaca, maka guru akan memahami dasar-dasar dan materi yang terkandungnya dan menjadikan sebagai bahan acuan dalam perencanaan.

Oleh karena itu, menurut analisa penulis maka perlu bagi guru untuk dibantu oleh supervisor di dalam mencarikan kurikulum, pedoman khusus mata pelajaran dan bahan-bahan lainnya yang berguna bagi perencanaan pembelajaran. Dari pengamatan penulis, ternyata masih banyak guru yang belum mempunyai bahan-bahan yang dimaksud dan kesulitan mencari bahanbahan tersebut.

Dari sejumlah pertanyaan yang berkaitan dengan kegiatan perencanaan, pada siklus I yang paling banyak adalah jawaban sering ( $\mathrm{sr}$ ) yaitu 44,44\%. Sedangkan jawaban selalu (sl) dan kadang-kadang $(\mathrm{kd})$ sama yang persentase perolehan jawabannya masing-masing 27,777\%. Hampir separuhnya dari persentase jawaban sering. Sementara persentase perolehan jawaban tidak pernah (tp) sebesar $0 \%$. Ini artinya jika guru diharapkan bahwa setiap akan membelajarkan siswa harus selalu merencanakan pembelajaran secara lengkap sesuai dengan indikator-indikator yang telah ditentukan, maka ada banyak guru yang belum dapat melaksanakan. Namun, keadaan ini memungkin untuk dapat diperbaiki. Mengingat jawaban sering cukup besar persentasenya dan jawaban tidak pernah sedikit persentase perolehannya. Dari beberapa pertanyaan yang mengukur ketercapaian komponen-komponen perencanaan, sebagian besar guru masih kesulitan memilahmilah antara aspek kognitif, aspek afektif dan aspek psokomotorik dalam tujuan pembelajaran. Banyak guru juga kurang kenal dan memahami model dan metode pembelajaran. Sehingga dalam perencanaan pembelajaranpun guru mengalami kesulitan di dalam membuat RPP. 
Kemampuan guru dalam pengelolaan kegiatan belajar mengajar dalam siklus I ini cukup rendah. Hal ini ditunjukkan oleh persentase perolehan jawaban untuk tingkat intensitas jawaban Selalu dan Sering Saya Lakukan keduanya di bawah 50 \%. Dengan memperhatikan jawabanjawaban atas pertanyaan pada setiap komponen kemampuan guru dalam pengelolaan KBM dapat dijelaskan bahwa penyebab rendahnya kemampuan guru dalam pengelolaan KBM antara lain: (1) lemahnya guru dalam mengelola ketertiban terutama kurangnya guru dalam memberikan pujian bagi siswa yang melaksanakan tata tertib dan lemahnya pemberian sanksi bagi siswa yang melanggar tata tertib, (2) masih banyaknya guru yang belum memahami secara utuh acuan kurikulum dan bahan ajar serta model dan metode pembelajaran sehingga pengelolaan pembelajaran menjadi kurang berkualitas, (3) minimnya penggunaan alat peraga dan media pembelajaran (hanya 20,83\% untuk jawaban SSL dan 37,5 \% untuk jawaban SL), (4) pengelolaan ruang kelas tidak maksimal sehingga kurang menyenangkan, dan (5) kurang otimalnya pengelolaan individu dan kelompok.

Oleh karena itu, dengan memperhatikan permasalahan di atas, maka supervisor memberikan bimbingan kepada guru agar dalam pertemuan berikutnya banyak memberikan pujian kepada anak, mau membaca dan memahami isi kurikulum, mau menggunakan alat dan media pembelajaran meskipun sederhana demi meningkatkan pemahaman konsep, membuat setting class yang menyenangkan serta menghidupkan suasana pembelajaran yang demokratis. Berdasarkan grafik hasil pengukuran di atas dapat disimpulkan bahwa kemampuan guru dalam evaluasi masih rendah. Persentase perolehan jawaban kadang-kadang sebesar 41,41\% dan tidak pernah $17,17 \%$. Ini artinya masih banyak guru yang belum melaksanakan penilaian kelas sesuai yang diharapkan. Dengan memperhatikan tiap-tiap item pertanyaan dalam instrumen beserta banyaknya jawaban dari subyek penelitian dapat diketahui bahwa sebagian besar guru kebanyakan hanya melakukan rutinitas penilaian seperti Ulangan Harian. Sementara penilaian lainnya seperti penilaian proses belajar jarang dilaksanakan.

Hasil pengukuran kemampuan Kepala Sekolah dalam pelaksanaan teknik supervisi observasi kelas pada Siklus I. Persentase perolehan jawaban Ya pada siklus I ini adalah 41,67 $\%$. Ini menunjukkan bahwa pelaksanaan teknik supervisi observasi kelas masih kurang. Hal ini mungkin disebabkan karena perencanaan supervisi belum dilaksanakan dengan secara optimal. Dengan memperhatikan tiap-tiap item pertanyaan dalam instrumen beserta banyaknya jawaban dari subyek penelitian dapat diketahui bahwa supervisor belum mengembangkan teknik-teknik supervisi secara optimal. Oleh karena itu, melalui diskusi dengan observer yang juga sebagai kolaborator, pada siklus II teknik-teknik supervisi akan dikembangkan dan dilaksanakan lebih mantap lagi dengan memberikan informasi atau pengarahan yang setepat mungkin pada guru agar tujuan supervisi dapat tercapai secara optimal.

\section{b. Siklus II}

Turunnya persentase perolehan jawaban B ternyata meningkatkan persentase perolehan jawaban A (73,33 \%). Ini menunjukkan bahwa sebenarnya guru-guru kelas SD Negeri 02 Talun memang memiliki motivasi yang tinggi dalam perencanaan. Masalahnya adalah bagaimana membekali mereka untuk dapat melaksanakan motivasi tersebut. Hasil Pengukuran Kemampuan Guru dalam Perencanaan KBM pada Siklus II jawaban selalu (sl) dan sering (sr) meningkat. Akibat persentase perolehan jawaban kadang-kadang turun menjadi 12,96\% sekitar separuhnya dari persentase semula. Ini artinya terjadi peningkatan kemampuan guru dalam merencanakan pembelajaran. Bimbingan supervisor yang diberikan kepada guru pada siklus I memberikan pengaruh pada peningkatan.

Pada siklus II ini secara umum untuk kemampuan guru dalam pengelolaan kegiatan belajar mengajar dalam siklus II ini mengalami peningkatan. Hal ini ditunjukkan oleh persentase perolehan jawaban untuk tingkat intensitas jawaban Selalu dan Sering Saya Lakukan (SSL dan SL) mengalami peningkatan akibat turunnya persentase perolehan jawaban kadang-kadang yang cukup tajam. Dengan memperhatikan jawaban-jawaban atas pertanyaan pada setiap komponen kemampuan guru dalam pengelolaan KBM dapat dijelaskan bahwa keadaan ini terjadi karena 
guru telah meningkatkan pemberian pujian bagi siswa yang melaksanakan tata tertib dan memberlakukan sanksi bagi siswa yang melanggar tata tertib, mulai mau membaca dan memahami secara acuan kurikulum dan bahan ajar serta model dan metode pembelajaran sehingga pengelolaan pembelajaran menjadi kurang berkualitas, mau menggunakan alat peraga dan media pembelajaran dan menghidupkan suasana belajar kelas yang aktif dan menyenangkan melalui belajar kelompok dan penataan ruang yang mnyenangkan.

Dengan memperhatikan grafik hasil pengukuran di atas dapat disimpulkan bahwa kemampuan guru dalam evaluasimasih cukup rendah. Persentase perolehan jawaban selalu dan sering masing-masing 20,707 dan 35,35\% yang mengalami sedikit peningkatan. Persentase perolehan jawaban kadang-kadang pun menurun sedikit. Ini artinya masih perlu proses perbaikan dari para guru dalam melaksanakan penilaian kelas. Dengan memperhatikan tiap-tiap item pertanyaan dalam instrumen beserta banyaknya jawaban dari subyek penelitian dapat diketahui bahwa perbaikan dapat dioptimalkan melalui pendidikan dan latihan assasment dan meningkatkan ketrampilan komputer. Sehingga guru dapat mebuat tabel dan grafik dalam soal dengan baik. Guru selanjutnya melalui pendidikan dan latihan tadi dapat mengembangan penilaiannya yang dapat mengukur tidak saja kemampuan kognitif tetapi juga kemampuan afektif dan psikomotorik. Hasil Pengukuran Kinerja Supervisor dalam Pelaksanaan Teknik supervisi observasi kelas pada Siklus II meningkat menjadi $75 \%$. Ini menunjukkan bahwa pelaksanaan teknik supervisi observasi kelas mengalami peningkatan setelah supervisor mau mengembangkan teknik-teknik supervisinya dengan berkolaborasi bersama guru-guru kelas. Sehingga terjadi diskusi pemecahan masalah bersama-sama dan mendorong terjadinya perbaikan dalam pembelajaran secara optimal.

\section{c. Pembahasan Antar Siklus}

Dengan memperhatikan hasil-hasil penelitian dan pembahasan tiap siklus, maka dapat diketahui bahwa terjadi peningkatan kemampuan guru dalam perencanaan pembelajaran, dalam pengelolaan kegiatan belajar mengajar dan dalam kegiatan evaluasi kegiatan belajar mengajar. Kualitas pelaksanaan teknik supervisi observasi kelaspun mengalami peningkatan. Hal ini ditunjukkan dengan adanya pergesaran peningkatan persentase perolehan jawaban dari jawaban tidak pernah, kadang-kandang, sering sampai selalu. Demikian pula terjadi dari jawaban D, C, B sampai A. Pergeseran peningkatan itu menggambarkan bahwa indikator-indikator kemampuan guru semakin banyak dilakukan dan ditingkatkan.

Adanya analisa data pengamatan terhadap guru dan pelaksanaan teknik supervisi observasi kelas membuat supervisor memantapkan lagi pelaksanaan supervisinya dengan teknikteknik yang sudah direncanakan dan secara tepat memberikan bimbingan dan pengarahan kepada guru dalam meningkatkan kemampuannya dalam pembelajarannya pada siswa SD Negeri 02 Talun.

\section{PENUTUP}

Berdasarkan hasil-hasil penelitian dan pembahasan dalam penelitian tindakan sekolah ini dapat disimpulkan bahwa dengan melaksanakan teknik supervisi observasi kelas maka kemampuan guru dalam perencanaan, pengelolaan dan evaluasi dalam kegiatan belajar mengajar mengalami peningkatan. Demikaian pula kualitas pelaksanaan teknik supervisi observasi kelas pun mengalami peningkatan. Ditunjukkan dengan adanya pergesaran peningkatan persentase perolehan jawaban dari jawaban tidak pernah, kadang-kandang, sering sampai selalu. Demikian pula terjadi dari jawaban D, C, B sampai A. Implikasi teoretis dari hasil penelitian ini adalah :a. Hasil penelitian ini dapat digunakan sebagai tambahan khasanah pengetahuan dan dasar pengembangan penelitian bagi Kepala Sekolah dalam rangka peningkatan dan perbaikan kualitas teknik supervisi observasi kelas. b. Dapat digunakan untuk meningkatkan hubungan yang sinergis antara guru dan Kepala Sekolah dalam meningkatkan mutu pendidikan dan pembelajaran. Implikasi praktis dari hasil penelitian ini adalah: a. Bagi para supervisor dapat digunakan sebagai acuan teknik supervisi observasi kelas dalam meningkatkan kemampuan merencanakan, 
melaksanakan dan evaluasi KBM. b. Bagi guru dapat memberikan motivasi yang tinggi dan arahan perbaikan dalam membelajarkan siswa.

\section{DAFTAR PUSTAKA}

Arikunto, S. (2004). Dasar-Dasar Supervisi. Jakarta: Rineka Cipta.

Davies, I .K. (1991). Pengelolaan Belajar. Jakarta: Rajawali

Departemen Pendidikan Nasional. (2002). Supervisi Pendidikan. Jakarta: Direktorat Pendidikan Lanjutan Menengah Pertama

Dharma, A. (2004). Manajemen Supervisi, Petunjuk Praktis Bagi Para Supervisor. Jakarta: PT.Raja Grafindo Persada.

Imron, A. (1995). Pembinaan Guru di Indonesia. Jakarta: Pustaka Jaya

Pidarta, M. (1992). Pemikiran Tentang Supervisi Pendidikan. Jakarta: Bumi Aksara

Pidarta, M. (2009). Supervisi Pendidikan Kontekstual. Jakarta: Rineka Cipta

Purwanto, N. (1987). Administrasi dan Supervisi Pendidikan. Bandung: Remaja Karya.

Suhertian, P. A. (2000). Konsep Dasar dan teknik Supervisi Pendidikan dalam Rangka Pengembangan Sumber Daya Manusia. Jakarta: Rineka Cipta.

Supriyadi, D. (1999). Mengangkat Citra dan Martabat Guru. Bandung: Adi Cita Karya Nusa

Suyanto. (2007). Tantangan Profesional Guru di Era Global. Yogyakarta: UNY Press.

Tembun, A. (1981). Super visi Pendidikan Penuntun Bagi Penilik Pengawas Kepala Sekolah dan Guru-guru. Bandung: Suri

Toha, M.C. (2003). Teknik Evaluasi Pendidikan. Jakarta: CV. Rajawali.

Undang-undang. (2003). UURI Nomor 20 Tahun 2003 Tentang Sistem Pendidikan Nasional. Jakarta: Sinar Grafika.

Undang-undang. (2005). UURI Nomor 14 Tahun 2005 Tentang Guru dan Dosen. Jakarta: Kemendikbud

Undang-undang. (2006). UURI Nomor 19 Tahun 2006 Standar Nasional Pendidikan. Jakarta: Kemendikbud

Uno, H., Firdaus, D., dan Sofyan, H. (2000). Perencanaan Pembelajaran. Jakarta: Alawiyah Press.

Usman, M. E. (2006). Menjadi Guru Profesional. Bandung: Rosdakarya. 